\title{
EHMTI-0330. The prevalence of undifferentiated connective tissue dysplasia syndrome in children with migraine
}

\author{
Y Nesterovskiy ${ }^{*}, \mathrm{~N}$ Zavadenko \\ From 4th European Headache and Migraine Trust International Congress: EHMTIC 2014 \\ Copenhagen, Denmark. 18-21 September 2014
}

\section{Background}

The efficiency of migraine therapy depends on it's comorbidities. One of these co-morbidities is represented by undifferentiated connective tissue dysplasia (UCTD). In general population the joint hypermobility syndrome (JHS) may be present in 5-30\% (Murray K.J., 2001) and minor congenital heart defects (MCHDs) in 5-35\% (Freed L.A., 1999). In adults approximately $75 \%$ of patients with JHM suffer migraine (Bendik E.M., 2011).

\section{Aim}

To study the manifestations of JHS and MCHDs in children and adolescents with migraine compared with their peers suffering tension-type headache (TTH).

\section{Method}

109 children and adolescents with migraine with/without aura established by the diagnostic criteria of ICHD-2 were included into the study. The control group included 50 patients with TTH. The JHS was confirmed according to P.H. Beighton's scored assessment (1999). MCHDs were diagnosed by the heart ultrasound examination.

\section{Results}

The signs of UCTD were revealed in 76 (69\%) of patients with migraine. JHS was confirmed in 68 (62\%). MCHDs were found in $42(38 \%)$.

In TTH patients the manifestations of UCTD were noted in only $21(42 \%)$ of cases in the form of JHS and in $9(18 \%)$ as MCHDs, which rates are similar to the literature data for general population.

Neurology Neurosurgery and Medical Genetics Department of Pediatric Faculty, N.I. Pirogov's Russian National Research Medical University, Moscow, Russia

\section{SpringerOpen ${ }^{\circ}$}

\section{Conclusion}

High prevalence of UCTD manifestations in child and adolescent migraine patients can influence the frequency and severity of migraine attacks and worsen the patients' somatic status which may have the negative influence on their quality of life.

No conflict of interest.

Published: 18 September 2014

doi:10.1186/1129-2377-15-S1-D44

Cite this article as: Nesterovskiy and Zavadenko: EHMTI-0330. The prevalence of undifferentiated connective tissue dysplasia syndrome in children with migraine. The Journal of Headache and Pain 2014 15(Suppl 1):D44.
Submit your manuscript to a SpringerOpen ${ }^{\circ}$ journal and benefit from:

- Convenient online submission

- Rigorous peer review

- Immediate publication on acceptance

- Open access: articles freely available online

- High visibility within the field

- Retaining the copyright to your article

Submit your next manuscript at $\boldsymbol{~ s p r i n g e r o p e n . c o m ~}$ 